\title{
Sistem Rekomendasi Distribusi Tetes Tebu Di UD. Lancar Menggunakan Metode Fuzzy Sugeno Berbasis Web
}

\author{
Yuliana $^{1}$, Fitri Marisa ${ }^{2}$, Dwi Purnomo ${ }^{3}$
}

\begin{abstract}
Commonly referred to as sugar cane waste molasses has many benefits among which for ethanol as a raw material, powder, toothpaste and also manufacture livestock. Since the number of industrial uses, making demand for the molasses to be increased. Many people use it for distribution business molasses. Due to many requests, making many entrepreneurs molasses ultimately have no part when there are large employers who are already bought. Based on the problems that have been described, was appointed research on the distribution system on molasses at UD. Lancar use of webbased Fuzzy Sugeno. The advantages of fuzzy methods is the decision-making by rank which will select the best alternative from a number of alternatives. The use of fuzzy logic simplify and streamline the use of an expert system that is implemented into machine language.
\end{abstract}

Intisari- Limbah tebu biasa disebut dengan tetes tebu atau molase memiliki banyak manfaat diantaranya yaitu untuk sebagai bahan baku ethanol, bedak, pasta gigi dan juga pembuatan ternak. Karena banyaknya industri yang menggunakan, membuat permintaan molase menjadi meningkat. Banyak masyarakat memanfaatkannya untuk usaha distribusi tetes tebu. Karena banyak permintaan, membuat banyak pengusaha tetes tebu akhirnya tidak mendapat bagian ketika ada pengusaha besar yang sudah terlebih dahulu membelinya. Berdasarkan masalah yang telah diuraikan, diangkat penelitian mengenai sistem rekomendasi distribusi tetes tebu di UD. Lancar menggunakan Fuzzy Sugeno berbasis web. Keunggulan metode fuzzy adalah pengambilan keputusan perangkingan yang akan menyeleksi alternatif terbaik dari sejumlah alternatif. Penggunaan logika fuzzy memudahkan dan mengefisienkan penggunaan sistem pakar yang diimplementasikan ke dalam bahasa mesin.

Kata Kunci- sistem penunjang keputusan, sistem rekomendasi, fuzzy sugeno, tetes tebu, sistem rekomendasi

\section{PENDAHULUAN}

1.1 Latar Belakang

Tebu merupakan tanaman yang tumbuh di tempat beriklim tropis. Diperkirakan daerah asal tebu adalah pulau Irian, lalu tanaman ini menyebar ke seluruh daerah tropis dunia. Tanaman ini sudah dibudidayakan secara besar-besaran terutama untuk diambil gulanya. Kandungan gula pada tebu diperkirakan sekitar $7-20 \%$, yang terbanyak terdapat pada batang bagian bawah, yakni sampai $20 \%$. Salah satu jenis sisa produk dari pengolahan tebu adalah molasse. Molasse adalah hasil samping dari kristalisasi gula yang berupa sirup berwarna merah coklat karena adanya reaksi browning.

${ }^{1}$ Mahasiswa, Teknik Informatika Universitas Widyagama Malang email: jointecs.uwg@gmail.com

${ }^{2,3}$ Dosen Pembimbing I, II, Jurusan Teknik Informatika Universitas Widyagama, Jln. Borobudur No. 35 Malang 65128 INDONESIA (telp: 0341-492282, 491648; fax: 0341-496919; email:fitrimarisa@widyagama.net ${ }^{2}$,purnomo_it@yahoo.com ${ }^{3}$
Limbah tebu yang biasa disebut dengan tetes tebu atau molasse memiliki banyak manfaat diantaranya yaitu untuk sebagai bahan baku ethanol, pembuatan balsam, bedak, pasta gigi dan juga pembuatan ternak. Selain itu, molasse juga dapat dimanfaatkan sebagai biofuel (bahan bakar alami). Karena banyaknya industri yang menggunakan, membuat permintaan molasse menjadi meningkat pula. Hal ini membuat banyak masyarakat memanfaatkannya untuk usaha distribusi molasse. Namun sayangnya karena banyak permintaan, membuat banyak pengusaha tetes tebu akhirnya tidak mendapat bagian ketika ada pengusaha besar yang sudah terlebih dahulu membelinya.

Berdasarkan masalah yang telah diuraikan tersebut, diangkat penelitian mengenai sistem rekomendasi distribusi tetes tebu di UD. Lancar menggunakan Fuzzy Sugeno berbasis web. Keunggulan metode fuzzy adalah proses pengambilan keputusan perangkingan yang akan menyeleksi alternatif terbaik dari sejumlah alternatif dan penilaian lebih tepat karena didasarkan pada toleransi terhadap data-data yang tidak tepat. Logika fuzzy mampu memodelkan fungsi-fungsi nonlinear yang kompleks dan merupakan metode yang mempunyai daya guna lebih baik daripada teknik lain. Penggunaan logika fuzzy memudahkan dan mengefisienkan penggunaan sistem pakar yang diimplementasikan ke dalam bahasa mesin. Hal ini disebabkan logika fuzzy mampu menjembatani bahasa mesin yang serba apresisi dengan bahasa manusia yang cenderung tidak presisi yaitu dengan menekankan pada makna atau arti (significance). Selain itu, konsep logika fuzzy mudah mengerti. Konsep matematis yang mendasari penalaran fuzzy sangat sederhana dan mudah dimengerti, memiliki toleransi data-data yang tidak tepat, membangun dan mengaplikasikan pengalaman-pengalaman pada pakar secara langsung tanpa harus melalui proses konvensional.

Berikut rumusan masalah :

1. Bagaimana membangun sistem rekomendasi distribusi tetes tebu di UD. Lancar menggunakan fuzzy segeno berbasis web sehingga distribusi tetes tebu dapat merata.

2. Bagaimana pengujian sistem rekomendasi distribusi tetes tebu di UD.Lancar menggunakan fuzzy sugeno berbasis web.

Batasan masalah pada penelitian ini :

1. Metode ini mengunakan fuzzy sugeno.

2. Aplikasi dibuat dengan bahasa pemrogaman PHP.

3. Faktor dan variabel yang menjadi pertimbangan dalam pengambilan keputusan meliputi 3 parameter yaitu rasa, kekentalan, dan kadar air.

4. Dalam sistem yang dibangun tidak disajikan secara online mengingat data-data yang diolah bersifat privasi. 


\section{LANDASAN TEORI}

\subsection{Sistem Pendukung Keputusan}

Salah satu metode komputasi yang cukup berkembang saat ini adalah metode sistem pengambilan keputusan (Decisions Support System). Dalam teknologi informasi, system pengambilan keputusan merupakan cabang ilmu yang letaknya diantara system informasi dan sistem cerdas. Konsep Sistem Pendukung Keputusan (SPK) / Decision Support System (DSS) pertama kali diungkapkan pada awal tahun 1970-an oleh Michael S. Scott Morton dengan istilah Management Decision Sistem. Sistem tersebut adalah suatu sistem yang berbasis komputer yang ditujukan untuk membantu pengambil keputusan dengan memanfaatkan data dan model tertentu untuk memecahkan berbagai persoalan yang tidak terstruktur.

\subsection{Logika Fuzzy}

Logika fuzzy adalah cabang dari sistem kecerdasan buatan (Artificial Intelegent) yang meniru kemampuan manusia dalam berfikir ke dalam bentuk algoritma yang kemudian dijalankan oleh mesin. Algoritma ini digunakan dalam berbagai aplikasi pemrosesan data yang tidak dapat direpresentasikan dalam bentuk biner. Logika fuzzy menginterpretasikan statemen yang samar menjadi sebuah pengertian yang logis.

Komponen-komponen fuzzy sebagai berikut :
a. Himpunan Fuzzy
b. Fuzzifikasi
c. Inferencing (Rule Base)
d. Defuzzifikasi

\subsection{Pengertian Tetes Tebu}

Molase merupakan limbah dari pengolahan tebu yang berbentuk cairan kental, berwarna coklat tua kehitaman, berbau manis atau harum. Molase termasuk medium pertumbuhan kompleks yang kaya akan sukrosa. Molase diperoleh dari tahap pemisahan Kristal gula yang tidak dapat dibentuk lagi menjadi sukrosa, namun masih mengandung gula dengan kadar tinggi (50-60\%), asam amino dan mineral (Suryana dkk, 2012).

Tetes tebu merupaan salah satu hasil samping yang dihasilkan dari pabrik gula yang masih mempunyai nilai ekonomi yang cukup. Hal ini disebabkan adanya kandungan gulanya yang masih tinggi yaitu sekitar $52 \%$, dengan komposisi $60 \%$ selulosa dan 35,5\% hemiselulosa. Kedua bahan polisakarida tersebut dapat dihidrolisis menjadi gula sederhana yang kemudian dapat difermentasi menjadi alkohol (Juwita, 2012). Industri yang memanfaatkan tetes diantaranya adalah industri yang menghasilkan produk distilasi seperti rum, alkohol, industri fermentasi seperti monosodium glutamat, lisin, asam sitrat, vinegar, protein sel tunggal, aseton-butanol, gum xanthan dan sebagainya (Fauzantoro, 2013).

\section{ANALISIS DAN PERANCANGAN SISTEM}

\subsection{Flow Chart Program Aplikasi Usulan}

Pada Gambar 3.1 menjelaskan proses berjalannya program, dimana penjual memasukkan data pembeli. Setelah itu, pembeli memasukkan 3 nilai kriteria pada setiap pembeli. Data tersebut diproses oleh fuzzy untuk diproses layak tidaknya pembeli tersebut. Hasil program ini berupa laporan, diantaranya laporan layak, tidak layak dan laporan pertanggal.

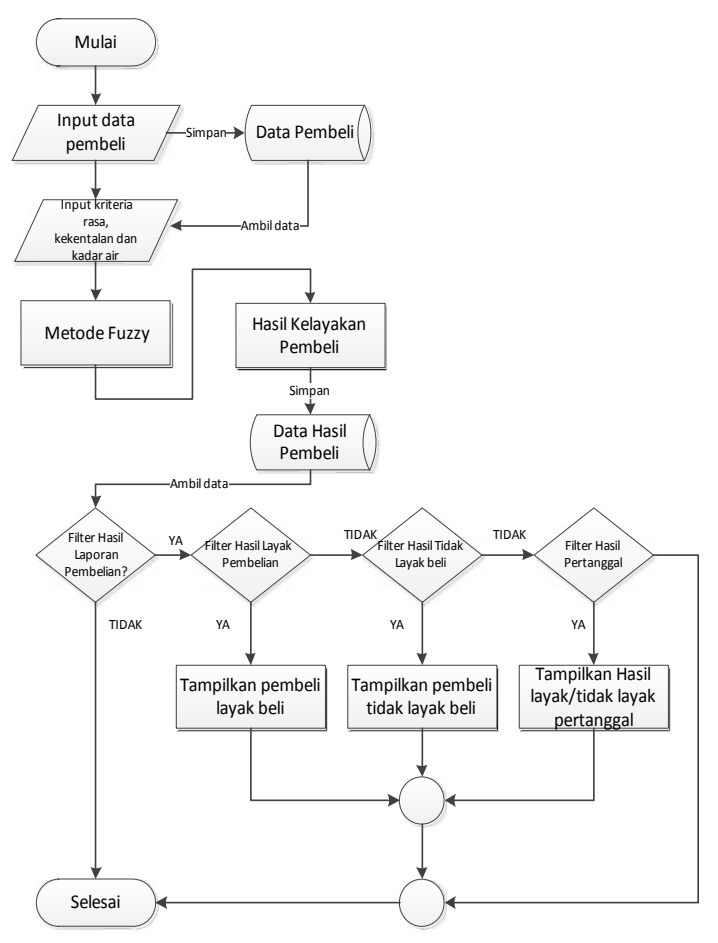

Gambar 3.1 Flowchart Aplikasi Usulan

\subsection{Data Flow Diagram}

\subsubsection{Conteks Diagram}

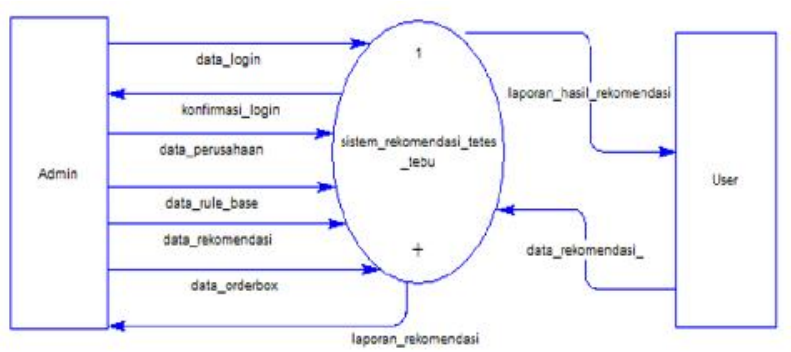

Gambar Conteks Diagram

\subsubsection{DFD Level 1}

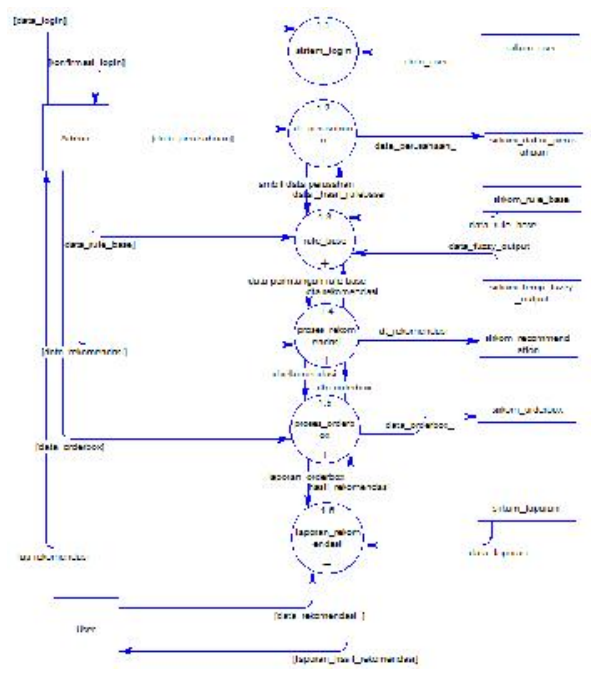

Gambar DFD Level 1 
3.2 Rancangan Database

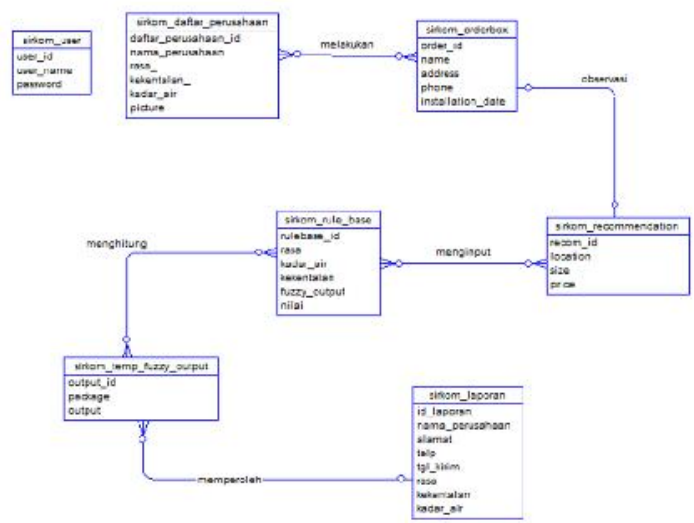

Gambar Relasi antar tabel database

\section{HASIL DAN PEMBAHASAN}

\subsection{Implementasi Antarmuka}

Implementasi antarmuka dilakukan pada setiap rancangan antarmuka yang dibuat kedalam bentuk aplikasi spk mesin. Implementasi sistem dimaksudkan untuk menjelaskan secara singkat hasil transformasi dari hasil perancangan kepada program aplikasi

\subsubsection{Form Daftar Rekomendasi Perusahaan untuk User \\ DAFTAR REKOMENDASI PERUSAHAAN

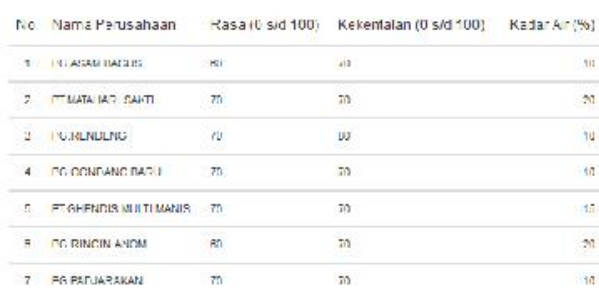

Gambar 4.1 Form Daftar Rekomendasi Perusahan

\subsubsection{Form Daftar Rekomendasi Perusahaan}

DAFTAR REKOMENDASI PERUSAHAAN tiniolit

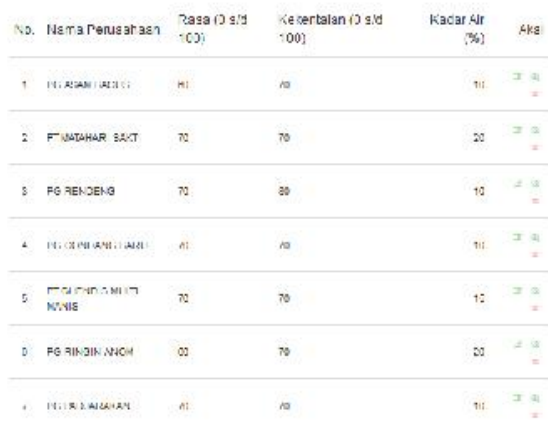

Gambar 4.4 Form Daftar Perusahaan

\subsubsection{Form Rule Base System}

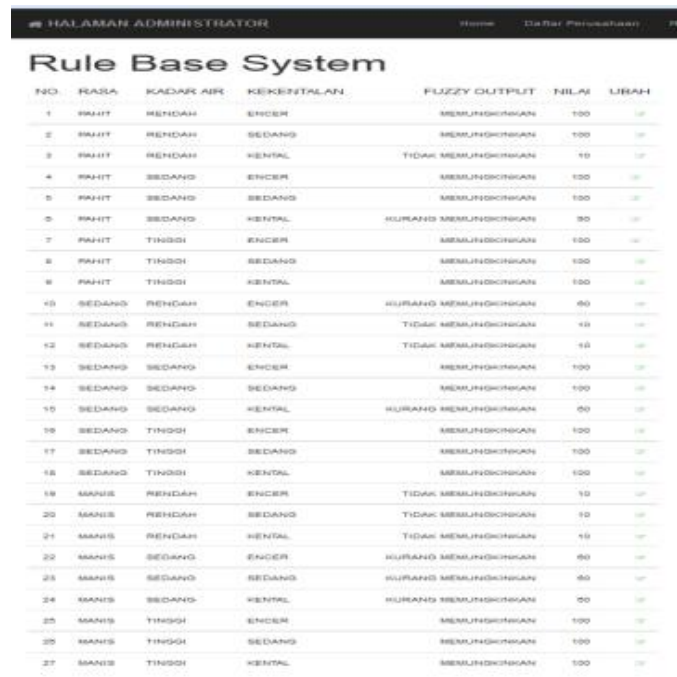

Gambar 4.5 Form Rule Base System

\subsubsection{Form Rekomendasi} Rekomendasi

\section{REKOMENDASI}

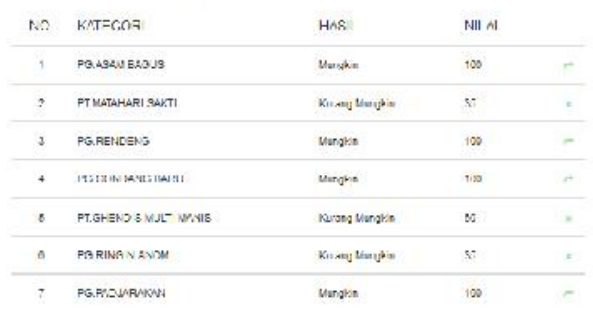

Gambar 4.6 Form Rekomendasi

\subsubsection{Form Pengiriman}

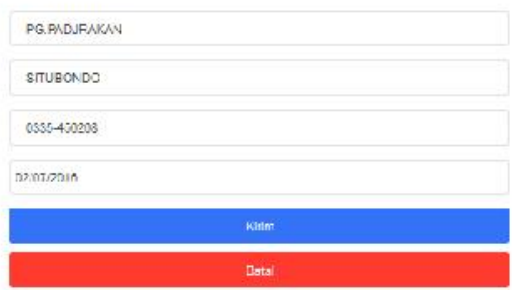

Gambar 4.7 Form Pengiriman

\subsubsection{Form Laporan Pengiriman}

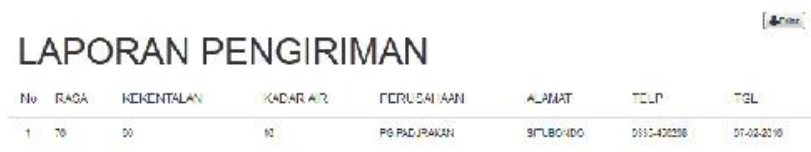

Gambar 4.8 Form Laporan Pengiriman 


\section{PENUTUP}

\subsection{KESIMPULAN}

Dari pembahasan dari implementasi sistem pada bab sebelumnya, maka dapat disimpulkan sebagai berikut :

a. Dengan adanya sistem rekomendasi distribusi tetes tebu di UD. Lancar menggunakan metode fuzzy sugeno berbasis web dapat membantu untuk merekomendasikan kepada pelanggan untuk distribusi secara merata

b. Memudahkan pemilih perusahaan gula untuk melakukan perhitungan terkait keputusan rekomendasi distribusi.

c. Sistem rekomendasi distribusi tetes tebu di UD. Lancar menggunakan metode fuzzy sugeno berbasis web telah berhasil mengembangan cara pengambil keputusan rekomendasi distribusi tetes tebu di UD. Lancar tersebut.

\subsection{SARAN}

Sistem penunjang keputusan yang telah dirancang dan implementasikan dalam skripsi ini jauh dari kata sempurna untuk itu diperlukan saran-saran :

a. Aplikasi ini dapat dikembangkan menggunakan metode yang lain yang keakuratan penentuan keputusannya lebih baik dari penelitian sebelumnya.

b. Tampilan dalam sistem ini dapat dikembangkan menjadi lebih baik dan lebih banyak layanan untuk user.

\section{REFERENSI}

[1] Cahyono, A, Tri., Sallu, Sulfikar dan Nikentari, Nerfita. 2014. Analisa Perbandingan SPK Menggunakan Metode Fuzzy Sugeno dan Tsukamoto. Jurusan Informatika, Fakultas Teknik Universitas Maritim Raja Ali Haji (UMRAH).

[2] Fauzantoro, R. A. 2013. Si Manis Beribu Manfaat. http://www.biotek.bppt.go.id/ index.php /artikel-sains/122-si-manisberibu-manfaat. Diakses pada tanggal 8 Oktober 2015.

[3] Girona. 2013. Sugeno Fuzzy Inference System. University College Cork. Ireland.

[4] Hendra dan A. Rochman. 2015. Implememtasi Fuzzy Logic pada Sistem Distribusi Buku untuk Memberikan Rekomendasi Jumlah Pengiriman. CSRID Journal, Vol. 7, No. 1, Februari 2015, Hal: 22-36.

[5] Jayanti, S dan Hartati, S. 2012. Sistem Pendukung Keputusan Seleksi Anggota Paduan Suara Dewasa Menggunakan Metode Fuzzy Mamdani. IJCCS, Vol.6, No.1, January 2012, pp. 55 66.

[6] Juwita, R. 2012. Studi Produksi Alkohol dari Tetes Tebu (Saccharum officinarum L.) selama Proses Fermentasi. Universitas Hasanudin. Makassar.

[7] Kusumadewi, S., dan Purnomo, S. 2010. Aplikasi Logika Fuzzy untuk Pendukung Keputusan. Penerbit: Graha Ilmu. Yogyakarta.

[8] Masykur, F. 2012. Implementasi Sistem Pakar Diagnosis Penyakit Diabetes Mellitus Menggunakan Metode Fuzzy Logic Berbasis Web. Universitas Diponegoro. Semarang.

[9] Purnomo, D, E, Prasetyo. 2013. Sistem Pendukung Keputusan Untuk Pemilihan Obyek Wisata di Surakarta Menggunakan Metode Fuzzy Tahani. Fakultas Teknologi Informasi : Universitas Stikubank Semarang

[10] Rachmaniah, M. W. Giam, R. S. B. Waspodo. 2012. Evaluasi Kesesuaian lahan untuk Pendugaan Debit Mata Air Menggunakan Metode Inferensia Fuzzy Sugeno. Jurnal Ilmu Komputer AgriInformatika, Vol. 1, No. 2, pp: 62-70.

[11] Rozi, D, J, Fachrur dan Yahya, Kresnayana.2013. Analisa Risiko Kredit Sepeda Motor Pada PT. X Finance (Studi Kasus Kantor Cabang Wilayah Gresik dan Lamongan) JURNAL SAINS DAN SENI POMITS Vol. 2, No.2, (2013) 2337-3520 (2301-928X Print).

[12] Suryana, R. N., T. Sarianti dan Feryanto. 2012. Kelayakan Industri Kecil Bioetanol Berbahan baku Molases di jawa Tengah. Jurnal Managemen dan Agribisnis, Vol. 9, No. 2, Juli 2012, Hal: 127-136.

[13] Susila, W. H., Wahyudi, I. Setiawan. 2011. Penggunaan Fuzzy Inference System Model Sugeno pada Pengendalian Suhu Ruangan. Universitas Negeri Diponegoro. Semarang. 